\title{
A case of CD10-negative angioimmunoblastic $T$ cell lymphoma with leukemic change and increased plasma cells mimicking plasma cell leukemia: A case report
}

\author{
YASUSHI ADACHI ${ }^{1,2}$, TAKUYA HINO ${ }^{3}$, MASAHIKO OHSAWA ${ }^{4}$, KAZUHITO UEKI $^{3}$, TOMOKO MURAO ${ }^{5}$, \\ MING LI ${ }^{2}$, YUNZE CUI ${ }^{2,6}$, MITSUHIKO OKIGAKI ${ }^{7}$, MITSUHIRO ITO $^{8}$ and SUSUMU IKEHARA ${ }^{2}$ \\ ${ }^{1}$ Division of Surgical Pathology, Toyooka Hospital, Toyooka City, Hyogo 668-8501; ${ }^{2}$ Department of Stem Cell Disorders, \\ Kansai Medical University, Hirakata City, Osaka 573-1010; ${ }^{3}$ Department of Internal General Medicine, Toyooka Hospital, \\ Toyooka City, Hyogo 668-8501; ${ }^{4}$ Department of Diagnostic Pathology, Osaka City University Graduate School of Medicine, \\ Osaka City, Osaka 545-0051; ${ }^{5}$ Department of Clinical Laboratory, Toyooka Hospital, Toyooka City, Hyogo 668-8501; \\ ${ }^{6}$ Japan Immunoresearch Laboratories Co. Ltd., Takasaki City, Gunma 370-0021; 7 Department of Internal \\ Medicine, Otokoyama Hospital, Yawata City, Kyoto 614-8366; ${ }^{8}$ Division of Medical Biophysics, \\ Kobe University Graduate School of Health Sciences, Kobe City, Hyogo 650-0017, Japan
}

Received August 29, 2014; Accepted May 22, 2015

DOI: $10.3892 / \mathrm{ol} .2015 .3490$

\begin{abstract}
Angioimmunoblastic T cell lymphoma (AITL) is a peripheral $\mathrm{T}$ cell lymphoma, known to express CD3 and CD4, and, frequently, also CD10 and c-Maf-1. Hypergammaglobulinemia is not particularly rare in patients with AITL. However, AITL in conjunction with plasmacytosis in the peripheral blood is rare. The current report presents a case of CD10-negative AITL demonstrating leukemic change and plasmacytosis in the peripheral blood mimicking plasma cell leukemia. A 78-year-old male was admitted to hospital due to systemic lymph node enlargement, high serum IgG and IgA, and increased counts of plasmacytoid cells and lymphoid cells with atypical nuclei in the peripheral blood. Initially, plasma cell leukemia was suspected, due to the extreme increase in the number of plasma cells in the peripheral blood. However, the plasma cells did not show clonal expansion on examination by flow cytometry. Based on histological analyses, following a biopsy of an enlarged lymph node, the patient was diagnosed with AITL. This case suggests that when hypergammaglobulinemia and increases in B-lineage cells are observed, AITL should be considered in addition to disorders of B-lineage cells.
\end{abstract}

Correspondence to: Professor Susumu Ikehara, Department of Stem Cell Disorders, Kansai Medical University, 2-5-1 Shinmachi, Hirakata City, Osaka 573-1010, Japan

E-mail: ikehara@hirakata.kmu.ac.jp

Key words: angioimmunoblastic $\mathrm{T}$ cell lymphoma, plasmacytosis, leukemic change, hypergammaglobulinemia, lymph node, peripheral blood, bone marrow

\section{Introduction}

AITL is the second most frequent subtype of peripheral $\mathrm{T}$ cell lymphoma in the Western world, accounting for $25-30 \%$ of peripheral $\mathrm{T}$ cell lymphoma cases and $2-4 \%$ of all cases of lymphoma (1). It has been reported that AITL presents with a number of clinical symptoms, including fever, weight loss, chills, skin rashes, pruritis, lymphadenopathy, hepatosplenomegaly, anemia, thrombocytopenia and hypergammaglobulinemia (2). Patients with AITL, frequently exhibit anemia, thrombocytopenia and lymphopenia in the peripheral blood. However, it is rare for patients with AITL to have numerous plasma cells in the peripheral blood, which is a feature more typical of plasma cell leukemia (3-5). The current report presents a case of a patient with AITL, in whom leukemic change and plasmacytosis were observed in the peripheral blood, bone marrow and lymph nodes.

\section{Case report}

A 78-year-old male was admitted to hospital, due to systemic lymph node swelling and an elevated number of white blood cells in comparison with normal levels, which had been detected by his family doctor 10 days previously. Upon physical examination, lymph nodes in the cervical region, supraclavicular fossa, axillary fossa and inguinal fossa were found to be enlarged to $40 \mathrm{~mm}$. The peripheral white blood cell count was elevated and numerous plasmacytoid cells without dysmorphic features, in addition to small-to-medium-sized lymphoid cells with atypical nuclei, were observed in his peripheral blood, as shown in Table I, Fig. 1 and Fig. 2A and B. 'Other' in the leukocyte classification in Table I, includes plasmacytoid cells (19\% of whole white blood cells) and lymphoid cells with nuclear atypia ( $22 \%$ of whole white blood cells). Anemia and low platelet numbers were also observed. Rouleaux formation was 
Table I. Laboratory results.

\begin{tabular}{|c|c|}
\hline Parameter & Result \\
\hline White blood cells & $332 \times 10^{2} / \mathrm{mm}^{3}(40-80)$ \\
\hline Myelocytes & $0.5 \%$ \\
\hline Band cells & $13.0 \%(5.0-6.0)$ \\
\hline Segmented neutrophils & $30.5 \%(40-60)$ \\
\hline Eosinophils & $3.0 \%(1.0-5.0)$ \\
\hline Basophils & $0.5 \%(0-1.0)$ \\
\hline Monocytes & $6.0 \%(3.0-5.0)$ \\
\hline Lymphocytes & $0.5 \%(30-40)$ \\
\hline Other & $46.0 \%$ \\
\hline Red blood cells & $310 \times 10^{4} / \mathrm{mm}^{3}(410-530)$ \\
\hline Hemoglobin & $9.6 \mathrm{~g} / \mathrm{dl}(13-17)$ \\
\hline Hematocrit & $28.7 \%(39-53)$ \\
\hline Mean cell volume & $92.3 \mathrm{fl}(85-102)$ \\
\hline Mean corpuscular hemoglobin & 30.9 pg (28.4-34.6) \\
\hline $\begin{array}{l}\text { Mean corpuscular hemoglobin } \\
\text { concentration }\end{array}$ & $33.4 \%(32.5-35.5)$ \\
\hline Platelets & $5.3 \times 10^{4} / \mathrm{mm}^{3}(12-35)$ \\
\hline INR & $1.63(1)$ \\
\hline Activated partial thrombin time & 51.1 seconds $(25-35)$ \\
\hline Fibrinogen & $62.7 \mathrm{mg} / \mathrm{dl}(150-350)$ \\
\hline Fibrin degradation products & $14.1 \mu \mathrm{g} / \mathrm{ml}(<10)$ \\
\hline D-dimer & $9.2 \mu \mathrm{g} / \mathrm{ml}(<1)$ \\
\hline Total protein & $10.6 \mathrm{~g} / \mathrm{dl}(6.7-8.0)$ \\
\hline Albumin & $2.0 \mathrm{~g} / \mathrm{dl}(3.4-4.9)$ \\
\hline Albumin fraction of protein & $25.0 \%$ \\
\hline$\alpha 1$ globulin fraction of protein & $1.6 \%$ \\
\hline$\alpha 2$ globulin fraction of protein & $2.4 \%$ \\
\hline$\beta$ fraction of protein & $2.8 \%$ \\
\hline$\gamma$ fraction of protein & $68.2 \%$ \\
\hline Total bilirubin & $1.6 \mathrm{mg} / \mathrm{dl}(0.2-1.0)$ \\
\hline Aspartate aminotransferase & 67 IU/1 (8-30) \\
\hline Alkaline phosphatase & 284 IU/1 (102-302) \\
\hline Lactate dehydrogenase & 1,031 IU/1 (106-211) \\
\hline$\gamma$-glutamyl transpepsidase & 33 IU/1 (8-64) \\
\hline Blood urea nitrogen & 22 mg/dl (8-20) \\
\hline Creatinine & 1.06 mg/dl (0.4-1.2) \\
\hline Glycosylated hemoglobin & $5.9 \%(4.4-5.9)$ \\
\hline C-reactive protein & $2.4 \mathrm{mg} / \mathrm{dl}(0-0.5)$ \\
\hline $\mathrm{Na}$ & 131 mEq/1 (134-145) \\
\hline $\mathrm{K}$ & 4.0 mEq/1 (3.6-5.0) \\
\hline $\mathrm{Cl}$ & 100 mg/dl (98-110) \\
\hline $\mathrm{Ca}$ & 8.4 mg/dl (8.0-10.2) \\
\hline $\operatorname{IgG}$ & $6,112 \mathrm{mg} / \mathrm{dl}(870-1700)$ \\
\hline $\operatorname{IgA}$ & $1,039 \mathrm{mg} / \mathrm{dl}(100-410)$ \\
\hline $\operatorname{IgM}$ & 176 mg/dl (35-220) \\
\hline IgG4 & 84.8 mg/dl (4.8-105) \\
\hline$\beta 2$ microglobulin & $13.42 \mathrm{mg} / \mathrm{dl}(0.9-2.1)$ \\
\hline Interleukin-2 receptor & $8,220 \mathrm{U} / \mathrm{ml}(145-519)$ \\
\hline Interleukin-6 & $10.8 \mathrm{pg} / \mathrm{ml}(<4)$ \\
\hline
\end{tabular}

Standard levels are noted in parentheses.
Serum protein electrophoresis

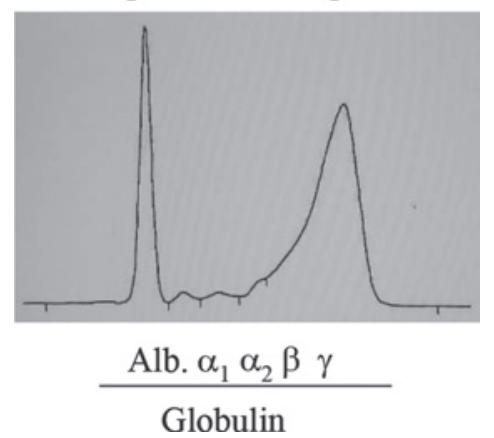

Figure 1. Serum protein electrophoresis.

noted in the peripheral blood, suggesting the occurrence of hyperviscosity syndrome, which is likely to have been due to hypergammaglobulinemia (Fig. 2A).

Biochemical examination demonstrated a coagulation abnormality, suggesting disseminated intravascular coagulation, with high levels of $\gamma$-globulin without M-peak, immunoglobulin G (IgG), IgA, lactate dehydrogenase, C-reactive protein, $\beta 2$-microglobulin, interleukin 2-receptor (IL-2R) and IL-6.

Flow cytometric analyses of the patient's peripheral blood demonstrated the $\mathrm{CD} 45^{\text {low }}$ population, including blastic cells, to comprise $16.9 \%$ of nuclear cells, while the CD $45^{\text {high }}$ lymphoid cell population comprised $39.2 \%$, as shown in Fig. 3A. Usually, $\mathrm{B}$ cells in the peripheral blood express both CD19 and CD20. However, of the CD $45^{\text {low }}$ population, there were lots of $\mathrm{CD} 19^{+} \mathrm{CD} 20^{-}$cells and these cells did not express the Ig light chain, indicating that the population included plasma cells or extremely immature B lineage cells. In addition, there was a marked elevation in the number of $\mathrm{CD} 38^{+}$cells without $\mathrm{MCP}-1$ expression, which formed $20 \%$ of the peripheral blood nuclear cells, as shown in Fig. 2B, suggesting an increase in immature plasma cells in the peripheral blood. These results were consistent with the complete blood counts (CBC; Table I), which showed that $19 \%$ of the whole white blood cells were plasmacytoid cells.

Within the $\mathrm{CD} 45^{\text {high }}$ population, the number of $\mathrm{CD} 4{ }^{+} \mathrm{CD} 3^{+}$ cells made up $\sim 30 \%$ of peripheral nuclear cells, which were negative for CD10. The CD4:CD8 ratio was $\sim 6: 1$, and the majority of the $\mathrm{CD}^{+}$cells did not express CD25. As noted, the percentage of small-to-medium-sized lymphoid cells with atypical nuclei had increased to $\sim 22 \%$ in the peripheral blood, suggesting that cells exhibiting this increase may be CD4 ${ }^{+} \mathrm{CD} 10^{-} \mathrm{CD} 25^{-} \mathrm{T}$ cell lymphoma/leukemia cells.

Enhanced computerized tomography demonstrated splenomegaly and splenic infarction (data not shown).

Upon examination of the bone marrow, the CD $45^{\text {low }}$ population, including blastic cells, was $67.7 \%$, and $89.3 \%$ of these were $\mathrm{CD} 19^{+}$. However, the $\mathrm{CD} 19^{+}$cells expressed neither CD20 nor surface Ig light chain (Fig. 3C). As shown in Fig. 3D, CD38 ${ }^{+}$cells made up $66 \%$ of the bone marrow nuclear cells. Of CD $38^{+}$cells, $13.3 \%$ were $\mathrm{MPC}-1^{+}, 45.6 \%$ were $\mathrm{CD}_{138^{+}}$and $95.8 \%$ were intracytoplasmic Ig light chain-positive, suggesting an elevation of plasma cells, particularly of immature plasma cells, in the bone marrow. These plasma cells did not exhibit clonal proliferation, since 

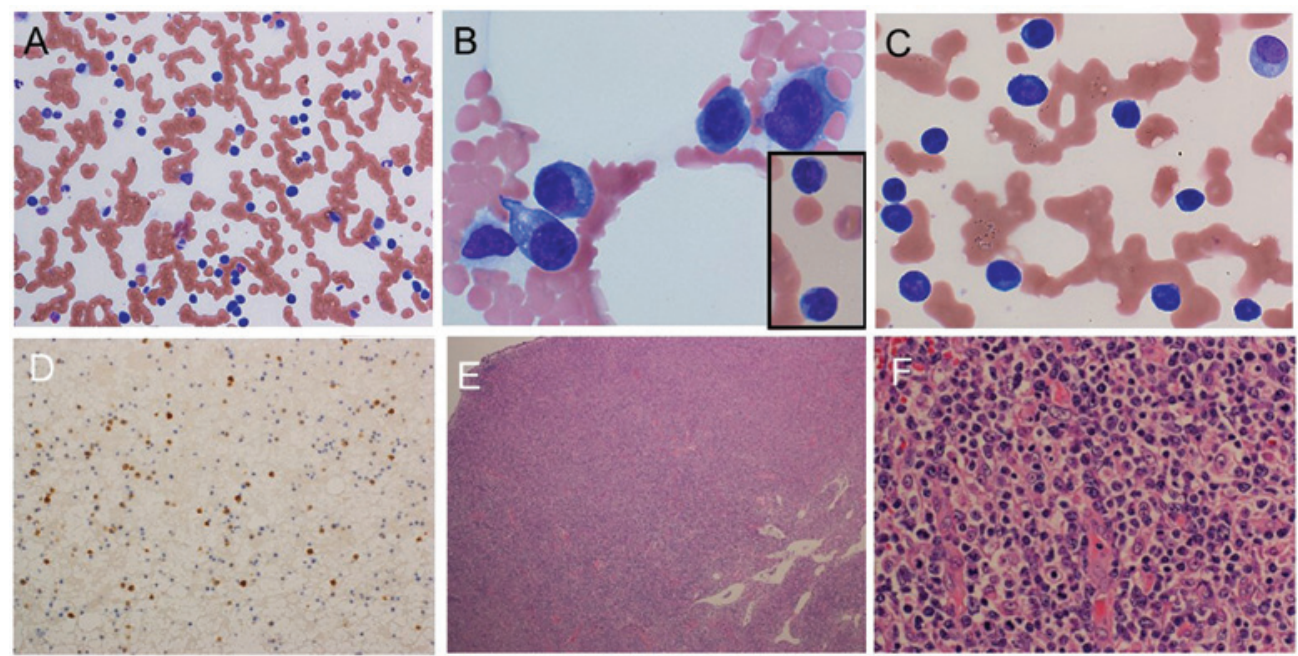

Figure 2. Morphological analyses of peripheral blood, bone marrow and lymph node specimens. (A) and (B) May-Giemsa stained smears of the peripheral blood (original magnification of the objective lens, x20 and x100, respectively). (A) Rouleaux formation is present. (B) Plasmacytoid cells and lymphoid cells with nuclear atypia (inset) are present. (C) May-Giemsa stained smear of the bone marrow (original magnification of the objective lens, x100). (D) Immunohistological staining of CD138 in formalin-fixed paraffin-embedded specimen of the bone marrow (original magnification of the objective lens, x20). (E) and (F) Hematoxylin and eosin staining of the lymph node specimen (original magnification of the objective lens, $\mathrm{x} 4$ and $\mathrm{x} 60$, respectively).

A
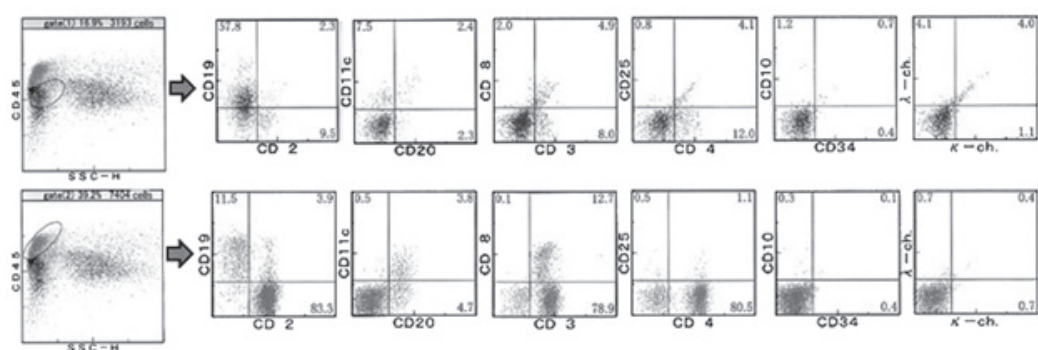

B
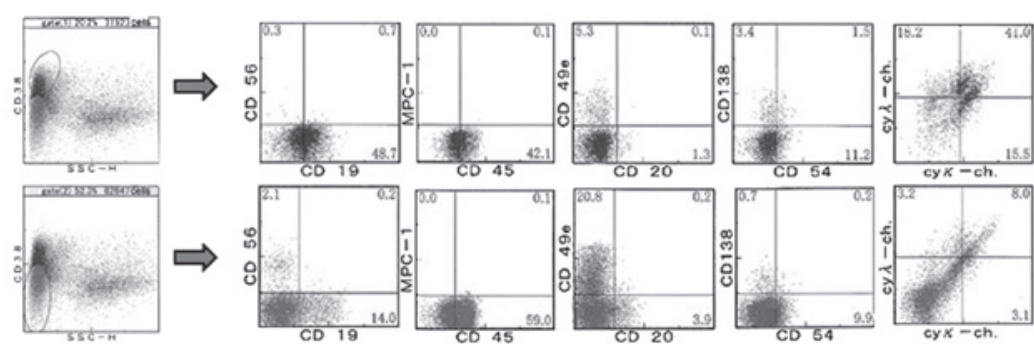

C
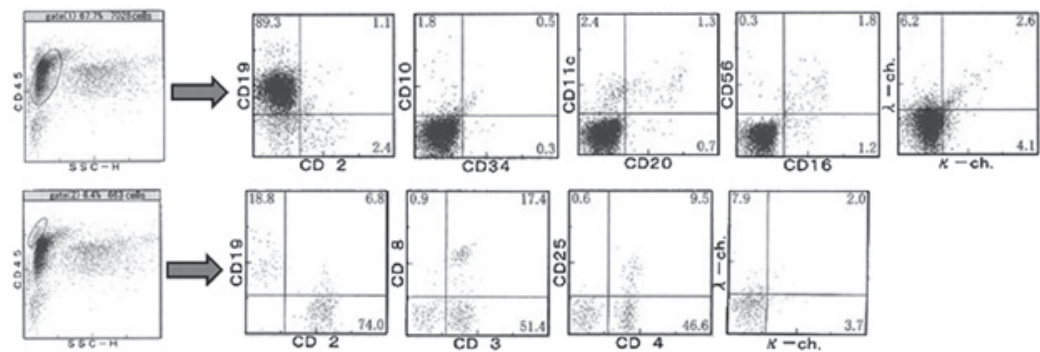

D
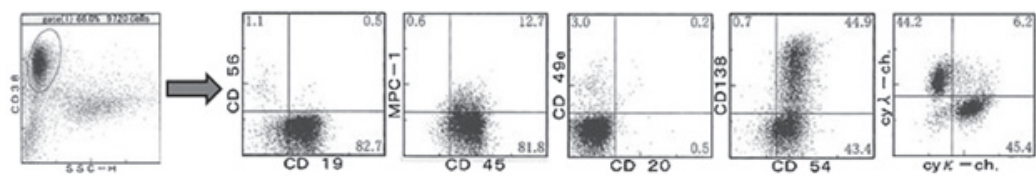

Figure 3. Flow cytometric analyses of the peripheral blood and bone marrow. Analyses were conducted using a flow cytometer. (A) Analyses of CD45 gates of the peripheral blood. The upper line shows analyses in the gate of $\mathrm{CD} 45^{\text {low }}$, including the blastic gate, while the lower line shows analyses in the CD45 lymphocyte gate. (B) Upper line shows the analyses in the CD38-positive cells, while the lower line shows the analyses in the CD38-negative cells in the peripheral blood. (C) and (D) Analyses of bone marrow cells. (C) Upper line shows analyses in the gate, including the blastic gate, while the lower line shows analyses in the lymphocyte gate. (D) Analyses in the CD38-positive gate. 
A
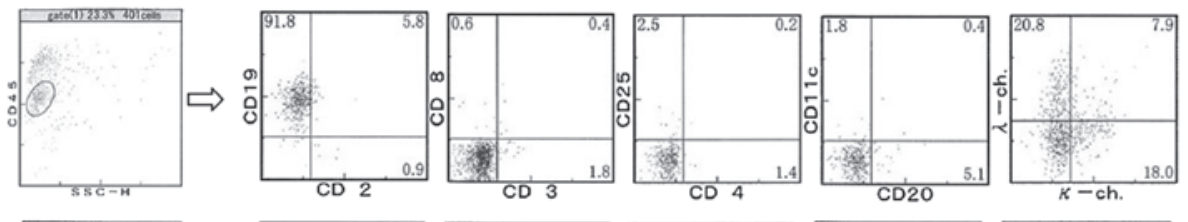

B
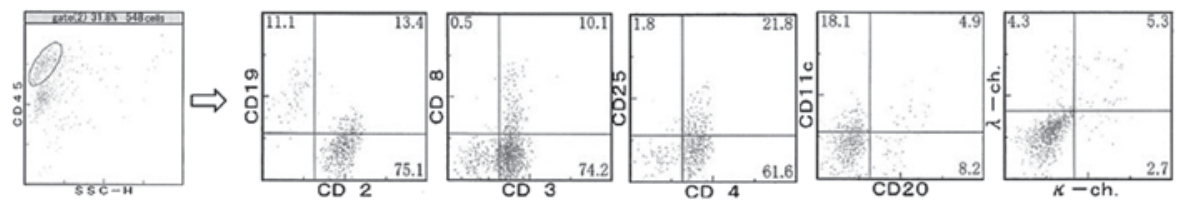

C
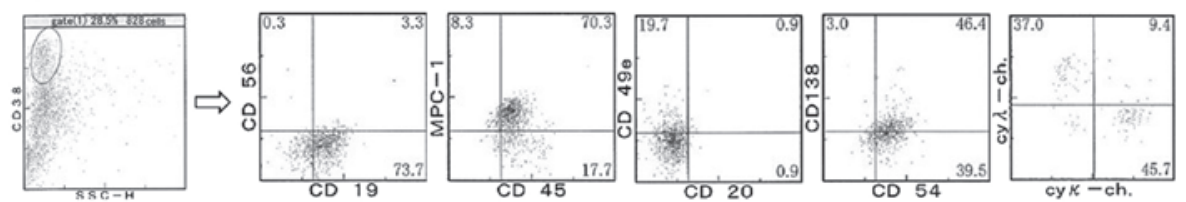

Figure 4. Flow cytometric analyses of the lymph node specimen. (A) Analyses in the gate, including blastic cells of CD45-positive cell. (B) Analyses in the lymphocyte gate. (C) Analyses in the gate of $\mathrm{CD} 38^{+}$.
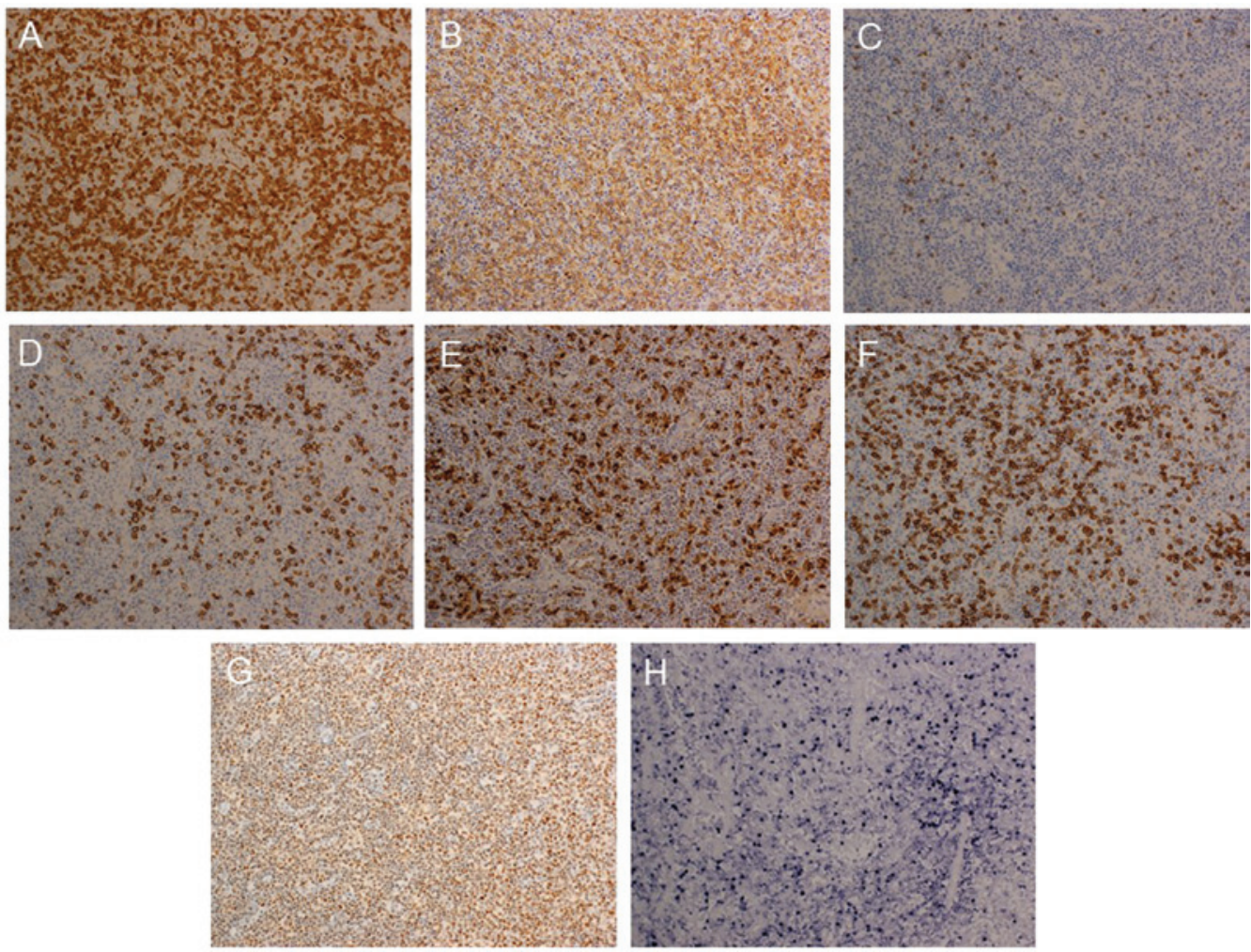

Figure 5. Immunohistological analyses and in situ hybridization for EBER within the lymph node. (A), (B), (C), (D), (E), (F) and (G) Expression of CD3, CD4, $\mathrm{CD} 8, \mathrm{CD} 20, \mathrm{CD} 68, \mathrm{CD} 138$ and c-MAF-1 in the lymph node speciment, respectively (original magnification of the objective lens, x20). Positive cells appear brown. (H) Expression of EBER (original magnification of the objective lens, x20). Positive cells appear navy-blue. EBER, Epstein-Barr virus-encoded small RNA.

the $\kappa: \lambda$ ratio in the Ig light chain was $\sim 1: 1$. In the lymphocyte gate, $\sim 70 \%$ of nuclear cells were $\mathrm{T}$ cells, and $>2 / 3$ of the $\mathrm{T}$ cells were $\mathrm{CD}^{+}$. In the May-Giemsa stained smear specimens of the bone marrow, small-to-medium-sized lymphoid cells with nuclear atypia were found (data not shown). The cells were similar to the small to medium sized lymphoid cells with nuclear atypia observed in the peripheral blood.

Subsequently, biopsies of an enlarged inguinal lymph node were taken. The normal architecture of the lymph node had been replaced by variously-sized, although predominantly medium-sized, lymphoid cells with clear cytoplasm, as shown in Fig. 2E and F. High endothelial venules were prominent (Fig. 2F). Upon flow cytometric analysis, $91.8 \%$ of the CD $45^{\text {low }}$ population, including blastic cells, were found to be $\mathrm{CD} 19^{+}$, while the majority of $\mathrm{CD} 9^{+}$cells were $\mathrm{CD} 20^{-}$, and half of $\mathrm{CD} 19^{+}$cells expressed Ig light chain, although the pattern of expression of light chains did not indicate clonal expansion. In the gate of CD45 $5^{\text {high }}$, a lymphocyte gate, $84.3 \%$ of cells were $\mathrm{CD}^{+}$, and nearly all were CD4 ${ }^{+}$(Fig. 4B). As shown in Fig. 4C, even in the lymph node, the percentage of $\mathrm{CD} 38^{+}$cells had 
risen to $28.5 \%$. These cells did not express CD20, while $77 \%$ expressed CD19, and $\sim 50 \%$ of expressed CD138. Unlike the peripheral blood and bone marrow samples, the $\mathrm{CD} 38^{+}$cells in the lymph node sample expressed MPC-1 and CD45, suggesting an increase in mature plasma cells in the lymph node. The majority of cells expressed cytoplasmic Ig light chain, although the $\kappa: \lambda$ ratio did not indicate clonal expansion.

Immunohistological analyses demonstrated a diffuse increase in $\mathrm{CD} 138^{+}$cells and $\mathrm{CD}^{+}$cells (T cells) within the lymph node specimen (Fig. 5). Among T cells, the number of $\mathrm{CD} 4^{+}$cells was markedly increased. Numerous Maf- $1^{+}$cells were observed in the lymph node, in addition to a diffuse distribution of Epstein-Barr virus (EBV)-encoded small RNA-positive cells.

In order to examine the clonal rearrangement of $\mathrm{T}$ cell receptor (TCR) and Ig, a PCR assay was conducted, as described in the European BIOMED-2 collaborative study (6). PCR indicated the presence of clonal rearrangements of TCR and Ig (data not shown).

Based on the histological features of the lymph node, the patient's symptoms, the increase in B-lineage cells without neoplastic light chain expression, the increase in $\mathrm{CD}^{+} \mathrm{T}$ cells with clear cytoplasm expressing Maf-1, and the presence of EBV-infected lymphoid cells, the patient was diagnosed with AITL with leukemic change. Following diagnosis, the patient died unexpectedly. No autopsy was permitted, and the exact cause of death therefore remains unclear, although hyperviscosity of the blood may have been a contributing factor. The family of the patient provided informed consent for the publication of this report.

\section{Discussion}

The current report discusses the case of a patient with CD10 AITL with leukemic change, plasmacytosis mimicking plasma cell leukemia and polyclonal hypergammaglobulinemia.

Examination of a lymph node biopsy demonstrated a histology typical of AITL, including completely effaced nodal architecture and the infiltration of medium-sized lymphocytes with clear cytoplasm, in addition to an inflammatory background. Furthermore, increased numbers of plasma cells and lymphoid cells with atypical nuclei were observed in the peripheral blood.

Plasma cell leukemia is defined as circulating peripheral blood plasma cells exceeding $2 \times 10^{9} / 1$ or $20 \%$ of peripheral white blood cells (7). In addition, the clonality of these plasma cells may be demonstrated by serum protein electrophoresis, flow cytometric analyses and/or Ig rearrangement. In the present case, $6.308 \times 10^{9} / 1$ and $19 \%$ of peripheral white blood cells were plasmacytoid cells. The serum $\gamma$-globulin was significantly elevated, while serum protein electrophoresis and flow cytometric analyses did not demonstrate any clonal proliferation of B-lineage cells.

The presence of plasmacytoid cells in the peripheral blood is occasionally observed during reactive processes, such as bacterial and viral infections, such as parvovirus B19, hepatitis or EBV; autoimmune disease, such as rheumatoid arthritis, systemic lupus erythematosus or Sjögren's syndrome; and serum sickness. However, in these conditions, the plasmacytoid cell counts are usually not notably elevated (8-16).
A number of cases of AITL with increased plasmacytoid cells in the peripheral blood, which is typical of plasma cell leukemia, have been reported (3-5). In these reports, the plasmacytoid cell counts in the peripheral blood were markedly elevated, although they did not exhibit clonal expansion. These reports were in accordance with the findings in the present case. In the case reported here, small-to-medium-sized lymphoid cells with atypical nuclei were also observed in the peripheral blood, and flow cytometric analyses demonstrated elevated CD4 $\mathrm{T}$ cell counts in the lymphocyte gate, suggesting leukemic changes, typical of AITL. Sakai et al (4) described a case of a patient with AITL, with plasmacytosis in the peripheral blood and leukemic changes, which is similar to the findings in the present case. Baseggio et al (17) attempted to detect $\mathrm{T}$ cells expressing $\mathrm{CD} 10$ in the peripheral blood of patients with AITL. In each of the 6 cases examined, the authors observed the presence of $\mathrm{T}$ cells expressing CD10 in the peripheral blood (mean percentage, 17\%; range, 5-58\%), while $\mathrm{T}$ cells in the control group were $\mathrm{CD} 10^{-}$, suggesting that lymphoma cells appear in the peripheral blood of patients with AITL to varying degrees.

In the present case, CD10 was negative, while c-Maf was positive, in lymphoma cells. A previous study reported that CD10 was detected in $39 \%$ of cases of AITL, suggesting that CD10 may a useful diagnostic tool in AITL, although it is neither particularly sensitive, nor specific to this disease (18). Furthermore, Murakami et al (19) reported that c-Maf may also be a useful marker of AITL. They reported that c-Maf expression was observed in 23 of 31 cases of AITL; 3 of 11 cases of adult T-cell leukemia/lymphoma; 4 of 19 cases of peripheral T-cell lymphoma, unspecified; 0 of 11 cases of mycosis fungoides; 0 of 11 cases of anaplastic large cell lymphoma; and 1 of 10 cases of extranodal NK/T-cell lymphoma, nasal type. Therefore, c-Maf appears to be relatively specifically expressed in AITL.

As previously described, AITL patients tend to be diagnosed at an advanced stage of disease. In the patient reported here, lymphoid cells with atypical nuclei were observed in the lymph node biopsy, and the peripheral blood and bone marrow at presentation. Furthermore, splenomegaly with infarction was detected, suggesting involvement of the spleen. These results suggest that the patient was at stage IV in the Ann Arbor staging system.

The current case report discussed the case of a patient with AITL, presenting with hypergammaglobulinemia, plasmacytosis, leukemic change, and clonal rearrangement of Ig and TCR. A diagnosis of AITL should be considered when encountering patients with polyclonal hypergammaglobulinemia and/or plasmacytosis.

\section{Acknowledgements}

The authors would like to thank Ms. K. Ando (Department of Stem Cell Disorders, Kansai Medical University, Hirakata, Japan) and Mr. Hilary Eastwick-Field (Department of Stem Cell Disorders, Kansai Medical University, Hirakata, Japan) for assistance with the preparation of this manuscript. The authors would also like to thank Mr. K. Nagaoka, Ms. H. Ogaki, Mr. T. Kuge, Mr. H. Takenaka and Ms. S. Eriguchi (Toyooka Hospital) for their expert technical assistance. 


\section{References}

1. Vose J, Armitage J, Weisenburger D; International T-Cell Lymphoma Project: International peripheral T-cell and natural killer/T-cell lymphoma study: Pathology findings and clinical outcomes. J Clin Oncol 26: 4124-4130, 2008.

2. Iannitto E, Ferreri AJ, Minardi V, Tripodo C and Kreipe HH: Angioimmunoblastic T-cell lymphoma. Crit Rev Oncol Hematol 68: 264-271, 2008.

3. Yamane A, Awaya N, Shimizu T, Ikeda Y and Okamoto S: Angioimmunoblastic T-cell lymphoma with polyclonal proliferation of plasma cells in peripheral blood and marrow. Acta Haematol 117: 74-77, 2007.

4. Sakai H, Tanaka H, Katsurada T, Yoshida Y, Okamoto E and Ohno H: Angioimmunoblastic T-cell lymphoma initially presenting with replacement of bone marrow and peripheral plasmacytosis. Intern Med 46: 419-424, 2007.

5. Ahsanuddin AN, Brynes RK and Li S: Peripheral blood polyclonal plasmacytosis mimicking plasma cell leukemia in patients with angioimmunoblastic T-cell lymphoma: Report of 3 cases and review of the literature. Int J Clin Exp Pathol 4 416-420, 2011

6. van Dongen JJ, Langerak AW, Brüggemann M, Evans PA, Hummel M, Lavender FL, Delabesse E, Davi F, Schuuring E, García-Sanz R, et al: Design and standardization of PCR primers and protocols for detection of clonal immunoglobulin and T-cell receptor gene recombinations in suspect lymphoproliferations: Report of the BIOMED-2 Concerted Action BMH4-CT98-3936. Leukemia 17: 2257-2317, 2003.

7. Kyle RA, Maldonado JE and Bayrd ED: Plasma cell leukemia. Report on 17 cases. Arch Intern Med 133: 813-818, 1974.

8. Gawoski JM and Ooi WW: Dengue fever mimicking plasma cell leukemia. Arch Pathol Lab Med 127: 1026-1027, 2003.

9. Li L, Hsu P, Patel K, Saffari Y, Ashley I and Brody J: Polyclonal plasma cell proliferation with marked hypergammaglobulinemia and multiple autoantibodies. Ann Clin Lab Sci 36: 479-484, 2006.
10. Koduri PR and Naides SJ: Transient blood plasmacytosis in parvovirus B19 infection: A report of two cases. Ann Hematol 72: 49-51, 1996.

11. Wada T, Maeba H, Ikawa Y, Hashida Y, Okumura A, Shibata F, Tone Y, Inoue M, Koizumi S, Takatori $\mathrm{H}$, et al: Reactive peripheral blood plasmacytosis in a patient with acute hepatitis A. Int $\mathrm{J}$ Hematol 85: 191-194, 2007.

12. Shtalrid M, Shvidel L and Vorst E: Polyclonal reactive peripheral blood plasmacytosis mimicking plasma cell leukemia in a patient with Staphylococcal sepsis. Leuk Lymphoma 44: 379-380, 2003.

13. Mori I, Parizot C, Dorgham K, Demeret S, Amoura Z, Bolgert F and Gorochov G: Prominent plasmacytosis following intravenous immunoglobulin correlates with clinical improvement in Guillain-Barre syndrome. PLoS One 3: e2109, 2008.

14. Touzeau C, Pellat-Deceunynck C, Gastinne T, Accard F, Jego G, Avet-Loiseau H, Robillard N, Harousseau JL, Bataille R and Moreau P: Reactive plasmacytoses can mimick plasma cell leukemia: Therapeutical implications. Leuk Lymphoma 48: 207-208, 2007.

15. Komiya I, Saito Y and Kuriya S: Peripheral blood plasmacytosis in a patient with infectious mononucleosis-like illness. Eur J Haematol 46: 61-62, 1991.

16. Thai KT, Wismeijer JA, Zumpolle C, de Jong MD, Kersten MJ and de Vries PJ: High incidence of peripheral blood plasmacytosis in patients with dengue virus infection. Clin Microbiol Infect 17: 1823-1828, 2011.

17. Baseggio L, Berger F, Morel D, Delfau-Larue MH, Goedert G, Salles G, Magaud JP and Felman P: Identification of circulating CD10 positive $\mathrm{T}$ cells in angioimmunoblastic T-cell lymphoma. Leukemia 20: 296-303, 2006.

18. Went P, Agostinelli C, Gallamini A, Piccaluga PP, Ascani S, Sabattini E, Bacci F, Falini B, Motta T, Paulli M, et al: Marker expression in peripheral T-cell lymphoma: A proposed clinical-pathologic prognostic score. J Clin Oncol 24: 2472-2479, 2006.

19. Murakami YI, Yatabe Y, Sakaguchi T, Sasaki E, Yamashita Y, Morito N, Yoh K, Fujioka Y, Matsuno F, Hata H, et al: c-Maf expression in angioimmunoblastic T-cell lymphoma. Am J Surg Path 31: 1695-1702, 2007. 